\title{
Ismertetés: Miért nem jó semmi, amit a szakember javasol? Az általános tervezéselmélet nehézségei
}

\author{
Dilemmas in a general theory of planning
}

Ismerteti: $\quad$ Csáki József Máté $\square$

Eötvös Loránd Tudományegyetem, Társadalomtudományi Kar

Szerzők: Rittel HWJ, Webber MM.

Megjelenés: Dilemmas in a general theory of planning. Policy Sciences, 1973;4(2):155-169. http://urbanpo-

licy.net/wp-content/uploads/2012/11/Rittel+Webber 1973 PolicySciences4-2.pdf

Beküldve: 2018. 08. 13.

doi: $10.24365 /$ ef.v59i4.347

Kulcsszavak: tervezéselmélet; szociálpolitika; ördögi problémák; szervezéstudomány; érdekérvényesítés

Keywords: theory of planning; social policy; wicked problems; planning science; advocacy

A szervezéstudományi szakirodalom e darabja hasznosnak bizonyulhat az egészségfejlesztésben részt vevők számára, hiszen olyan szociálpolitikai problémák kezelésével kapcsolatban nyújt segítséget, amelyekre eddig nem kaptak kielégítő megoldásokat. A szakmailag megalapozott intézkedéseket övező növekvő elégedetlenséget és a szakemberekre nehezedő nyomást úgy véli mérsékelhetőnek az olvasmány, ha figyelmünket az elmúlt évszázadban kibontakozó, napjainkban is zajló társadalmi változásokra fordítjuk.

A szakemberek munkamódszereinek kognitív aspektusait a múlt század elején tökéletesítették, és ezek rendkívül hatékonynak bizonyultak az olyan, elosztással és infrastruktúrával kapcsolatos tervek kivitelezésére, mint az útépítés, a közmúvesítés, a betegségek visszaszorítása, az iskolák és a kórházak befogadóképességének növelése stb. A viszonylag egyszerű problémák megoldását és egy egyetemesen kívánatosnak tûnő állapot elérését követően számos társadalmi csoport újabb, egymás érdekeitôl nemcsak eltérő, hanem azokkal sokszor ellentétes igényekkel lépett fel; olyan igényekkel, amelyekre nem lehet válaszolni, ha nem ismerjük a nyilt társadalmi rendszer működését. Az infrastrukturális problémák megoldására létrehozott eljárások értéküket vesztik a társadalmi szférába való átemelésükkor, és alkalmazásukkal nem lehet hatékony eredményekre számítani.

Egy probléma megfogalmazásának és egyik lehetséges megoldásának fokozatosan kell kialakulnia, szakmai vita során, egymás mellett felsorakozó érvek és folytonosan felmerülő bírálatok mentén. E folyamat megindítása nélkül a társadalompolitikai problémák "ördögi problémákká" (wicked problems) válnak, és a velük kapcsolatban hozott döntések nem felelnek meg teljes mértékben a közjónak, nem teljesítik maradéktalanul a méltányosság követelményeit, és nem értékelhetők az objektivitás konvencionális kritériumai alapján. Valamennyi társadalmi probléma ördögi problémának számít, legyen szó egy új autópálya vagy erőmú építéséről, adókulcs módosításáról, tanterv kialakításáról, a bűnmegelőzés egy új irányának meghatározásáról stb. A társadalmi problémák kezelését nem csak az nehezíti meg, hogy kognitív 
struktúráink kiforratlanságából adódóan nem látjuk tisztán a társadalmi szféra összetett ok-okozati viszonyait; e feltérképezetlen rendszerekbe való durva politikai beavatkozás tovább torzítja az összefüggésrendszerről alkotott képet. Ördögi problémák a célmegállapítás, a problémameghatározás és a méltányossággal kapcsolatos nehézségek metszetében születnek; ezeket területeket kell áttekinteni ahhoz, hogy megértsük, mi kölcsönöz e problémáknak ördögi minőséget.

\section{CÉLMEGÁLLAPÍTÁS}

Az 1960-as évek elején különböző intézmények és testületek ${ }^{1}$ adtak ki olyan jelentéseket, melyek az Egyesült Államok által elérendőnek tekintett célokat tartalmaztak. A rejtett nemzeti célok e formális kifejeződése jelentős ellentétbe került a fekete polgárjogi, a hallgatói és a háborúellenes mozgalmak szándékaival, illetve a konzervativizmus és a fogyasztói társadalmi jelenségek ellenzői által kitűzött célokkal. Függetlenül a célkitűzések tartalmától, megfogalmazásukkal a közpolitika minden szereplője ugyanazt kívánta elérni sajátos szempontjait hangsúlyozva: tisztázni a szándékokat; újbóli meghatározását adni a problémáknak; újrarendezni a megoldásukat szolgáló múveletek fontossági sorrendjét; célorientáltabb eszközöket létrehozni, végül újra elosztani a kormány által különböző célokra biztosított ráfordításokat. A szociális szakmák képviselői a professzionalizmusba vetett hitük alapján úgy vélik, ismereteik tudományosan eléggé megalapozottak ahhoz, hogy végrehajtsák a szociálpolitikai intézményrendszer e nagyszabású átalakítását.

A drogok tárgykörébe tartozó, szinte minden eset ördögi problémának tekinthető. A drog tárgyszerú gyógyszerészeti meghatározásánaki,2 normatív értékelése nagymértékben társadalmilag befolyásolt. Különböző társadalmi szereplők célmegállapításának függvénye, hogy a drogok milyen széles körét vonják szabályozás alá, kik vehetnek részt a gyártásukban, kik az elosztásukban; mely fajtáikat kik használhatják, melyek az általános körben elérhetők, melyekhez biztosíthat hozzáférést egy szakember, és melyekhez lehet csak illegálisan hozzájutni stb. A drogokkal kapcsolatos erkölcsi hozzáállás, a gazdasági berendezkedés, a szakemberek állásfoglalása, a lobbik jelenléte, a szubkultúrák megítélése mind meghatározza, hogy a drogokkal kapcsolatos tevékenységek közül melyeket tekintik beavatkozást igénylőknek. ${ }^{3}$

\section{PROBLÉMAMEGHATÁROZÁS}

A szociálpolitikai szervezés során a legnagyobb nehézséget maguknak a problémáknak a meghatározása és forrásuk azonosítása jelenti, azaz hogy mi különbözteti meg a megfigyelt állapotot egy kívánt állapottól, illetve hogy az összetett ok-okozati hálózatok sokaságában melyik csomópont a probléma valódi forrása. Szükséges továbbá meghatározni azokat a beavatkozásokat, amelyek közelebb visznek minket az ideális állapot eléréséhez. A nyílt társadalmi rendszerről alkotott tudásunk kifinomultabbá válása azonban nemcsak e múveletek hatásfokát növeli, hanem kiterjesztve a rendszer határait, egyre messzebbre kerülünk egy működőképes szervezéstudományi (planning science) rendszer létrehozásától. A követendő példa ez esetben a tervezés modern-klasszikus modellje lenne, ami rendkívül dinamikus eljárásokat foglal magában: egy időben, állandóan, ismétlődve, időzítve folynak benne olyan múveletek, mint az irányítás, a célkeresés, a problémameghatározás, az előrejelzés, a megfigyelés, az utánkövetés, a hibajavítás stb. Ennyire átfogó rendszer működtetése pillanatnyilag lehetetlen, de nem csak ennek a mikéntje bizonytalan: sokan kétségbe vonják, hogy célszerű lenne-e egy ennyire szerteágazó struktúra múködésbe hozása.

Az Egyesült Államokban komoly problémát jelent a receptköteles gyógyszerekkel való visszaélés ${ }^{4}$. A problémát több oldalról próbálják megközelíteni, hiszen receptköteles gyógyszerek a gyógyszertáron kívül származhatnak rokontól, ismerőstől, illegális internetes patikából, gyógyszerlopásból, drogkereskedőtől, illetve hozzáférhetők illegálisan felírt vagy hamisított recepteket felhasználva. E források azonosítását követően a szakember határozza meg, hogy mely szereplőkkel kíván együttműködni, mely ágenseket fogja szabályozni, mely résztvevőket

\footnotetext{
' „Olyan ismert szerkezetű vegyület (kivéve tápanyagok), mely élő szervezetbe juttatva biológiai hatást fejt ki.” Szintúgy drognak tekinthető a kávé és a heroin.
} 
akarja szankcionálni. Megoldás lehet különböző oktatási stratégiák beiktatása, amelyek az orvosokat megtanítják, miről lehet felismerni, ha egy páciens illegális gyógyszerhasználat céljával kér receptet, vagy a betegeket arra, miként kezelhetik krónikus fájdalmaikat ópiátok felhasználása nélkül, és hogy általában tartózkodjanak a droghasználattól ${ }^{5}$. Meg lehet célozni a receptköteles gyógyszerekkel való kereskedelem visszaszorítását. Gyógyszerészeti technológiák segítésével olyan, manipulálással szemben álló készítményeket lehetne gyártani, melyek kizárólag rendeltetésüknek megfelelően használhatók ${ }^{6}$. Arra az általános kérdésre is irányíthatnánk figyelmünket, hogy kik azok, akik visszaélnek ezekkel a szerekkel és miért, hiszen a receptköteles gyógyszerek abúzusa nagyobb társadalmi problémák tünete. Bárhonnan is közelítjük meg, az ördögi problémák ok-okozati láncolatának elméletben nincs vége; a láncolatot különböző erőforrásokkal kapcsolatos gyakorlati szempontok anyagi, időbeli, humán tényezők - szakítják meg, és ezekhez mérten születnek „elégséges” megoldások.

\section{MÉLTÁNYOSSÁG EGY HETEROGÉN TÁRSADALOMBAN}

A nyugati társadalmak népességszáma igencsak megnövekedetti", ami az ötvenes évekbeli „kváziszociológiai” elméletek tükrében nem is lett volna akkora probléma a társadalompolitikai szervezés számára. Ezek az elméletek olyan tömegtársadalmak létrejöttét vetették fel, amelyeknek a legtöbb tagja egyazon kultúrán osztozik, kevés mozgástérrel rendelkezve az attól való eltéréshez. A nyugati társadalmak ehelyett - továbbra is nagy kiterjedés mellett - rendkívüli mértékű differenciáción mentek keresztül a csoportok közös érdekeinek és értékrendszereinek tekintetében. E folyamat mellékterméke megszámlálhatatlan mennyiségú kulturális variáció, melyek végterméknek azért nem tekinthetők, mert egy látszólag további differenciációra képtelen csoportból is válhat ki egy még specifikusabb jegyekkel rendelkező, kisebb létszámú csoport.
Az általános közjó fogalma felett eljárt az idő. Nincs két olyan csoport, amelyik a szociálpolitikai döntést igénylő kérdésekben maradéktalanul egyetértene. A legtöbb társadalmi folyamat a játékelmélet képviselői által leírt nulla összegú játszmákra hasonlitit. A nulla összegú játszmák nyereménye véges mértékű, így egy játékos nyeresége szükségszerűen a többi játékos veszteségét jelenti. Egy magas fokon diverzifikálódott társadalom csoportkülönbségei hamar csoportellentétekké válhatnak egy olyan állandó összegú játszmában, mint a (társadalom) politikai érdekérvényesítés. Elmondhatjuk tehát, hogy a különböző társadalmi csoportok által képviselt értékek és érdekek nehezen egyeztethetők össze, főleg egy minden sajátos érdeket felülíró, általános közjót képviselő társadalmi elmélet vagy etika hiányában. Ehhez hasonló „totális elmélet” hiányában a szakemberek nem tudják előállítani a jólét aggregált mércéjét az objektivitás és a pártatlanság követelményeinek megszegése nélkül. A társadalompolitikai szervezés szükségképpen politikai állásfoglalással is jár.

Számos érdek játszik közre, amikor a receptköteles gyógyszerek abúzusáról van szó. A vonatkozó érdekek összeférhetetlenségére akkor derül fény, amikor adott csoport tevékenységét befolyásolva próbálnak meg változást előidézni. Törvénybe foglalva, hogy a gyógyszergyártóknak bizonyos hatóanyagok csoportját olyan készítmények formájában kell forgalmazniuk, amelyek nem teszik lehetővé a rendellenes használatot, a gyártók a szabadpiaci versenyre hivatkozva tiltakozhatnak a döntés tényleges végrehajtása ellen. Az orvosok visszautasíthatják, hogy a visszaélések felismerésére irányuló oktatást kötelezővé tegyék számukra, hiszen egyébként is leterheltek, és az orvosi gyakorlatban eszközölni kívánt változtatások fenyegetik szakmai autonómiájuk. A kórházak sürgethetik a döntéshozás felgyorsítását tekintettel arra, hogy a nem orvosi célra felhasznált készítményeket túladagoló betegek ellátása az intézmények infrastrukturális forrásainak nagy részét emészti fel, ${ }^{6}$ mely sürgetett eljárás szintén vitás állapotot idézhet elő, hiszen nem minden csoport érdekei kerülnek mérlegelésre. Az érdekérvényesítés így kétségkívül fontos katalizátora a döntéshozási folyamatnak.

"Erről adott számot a tanulmány 1973-ban. A 2016-os ENSZ Demográfiai évkönyv tanúsága szerint a nyugati társadalmak növekedése napjainkig töretlen. https://unstats.un.org/unsd/demographic-social/products/dyb/documents/dyb2016/table01.pdf 


\section{TANÁCSOK A HAZAI SZAKEMBEREK SZÁMÁRA}

E társadalompolitikai szervezési problémák „ördögi” természete nem a velük kapcsolatos értékítélet megfogalmazásából ered, hanem abból a tényből, hogy a természettudományos problémákkal ellentétben nem írhatók körül pontosan, rosszul meghatározottak, és - a legfontosabb - nem lehet valódi megoldást találni rájuk, kizárólag határozni lehet az ellenük bevethető taktikákról, politikai mérlegelést követően iii. Ha megszületik a cselekvési terv, nem mondható el róla biztosan, hogy a kontextuális ismeretek széles körének figyelembevételével jött létre, így a hiányos megértés súlyosbítja a szociálpolitikai döntéshozás következményeit, amelyek annak múködési elvei miatt álltak elő. A különböző beavatkozások ugyanis olyan hatásokat fejtenek ki, amelyeket adott törvények vagy rendelkezések visszavonásával nem lehet semlegesíteni.

Teljes mértékben a szakemberen múlik, hogy a problémát milyen szintről közelíti meg. A tünetek alacsony szintjéről felfelé haladva a probléma általánosságának egyre magasabb fokaival találkozunk, és a megértésük is egyre nehezebbé válik. A tüneti kezelés azonban nem helytálló megoldás, a szakember a probléma minél általánosabb körének megoldására kell hogy törekedjen. Ismerjük fel, hogy amikor tüneti kezelésre készülünk, ördögi problémával van dolgunk! Javasolt megoldásai nem értékelhetők a ",helyes-helytelen”, az „igaz-hamis” kritériumai alapján, inkább olyan ismérvekkel jellemezhetők, mint a „jobb”, a „rosszabb”, a „kielégíto”, vagy az „elég jó". Ne feledjük, hogy a társadalompolitikai vitának nem csak pártatlan megfigyelői vagyunk, és időről időre tegyünk fel a rendszer múködésével és múködtetésének céljával kapcsolatos kérdéseket!

\section{HIVATKOZÁSOK}

\footnotetext{
${ }^{1}$ American Assembly. Goals for Americans Comprising the Report of the President's Commission on National Goals and Chapters Submitted for Consideration of the Commission. New York: Columbia University Press, 1960. https://babel.hathitrust.org/cgi/pt?id=mdp.49015000077488;view=1up;seq=1 Elérve: 2018. 09. 14.

${ }^{2}$ Rang HP, Dale MM, Ritter JM, Flower RJ. What is Pharmacology. In: Rang \& Dale's pharmacology (6th ed.). Edinburgh: Churchill Livingstone, 2011. p. 1.

${ }^{3}$ Conrad P, Schneider JW. Opiate Addiction The Fall And Rise Of Medical Involvement. In: Deviance and Medicalization: From Badness to Sickness. Expanded edition. Philadelphia: Temple University Press, 1992. p. 110-144.

${ }^{4}$ Lessenger JE, Feinberg SD. Abuse of Prescription and Over-the-Counter Medications. Clinical Review, 2008 Vol. 21 No. 1. doi: 10.3122/jabfm.2008.01.070071

${ }^{5}$ Manchikanti L. National Drug Control Policy and Prescription Drug Abuse: Facts and Fallacies. Pain Physician, 2007;10:399-424. https://www.ncbi.nlm.nih.gov/pubmed/17525776 Elérve: 2018. 09. 14.

${ }^{6}$ Hernandez SH, Nelson LS. Prescription Drug Abuse: Insight Into the Epidemic. Clinical Pharmacology \& Therapeutics, 2010;88(3):307-317. doi: 10.1038/clpt.2010.154.

${ }^{7}$ Elster J. Racionális döntések. In: Felkai G, Némedi D, Somlai P (szerk.). Szociológiai irányzatok a XX. században. Budapest: Új Mandátum Kiadó, 2000. p. 215-231.
}

\footnotetext{
iii A szerző a 'solution' és a 'resolution' szavakat használja. Ebben a kontextusban a megoldás (solution) olyan eljárást jelent, ami nem igényel további beavatkozást, a problémát vélhetően elhárító módszerről pedig határozni (resolution) tudnak, ami viszont nem garantálja annak végleges megszúnését.
} 